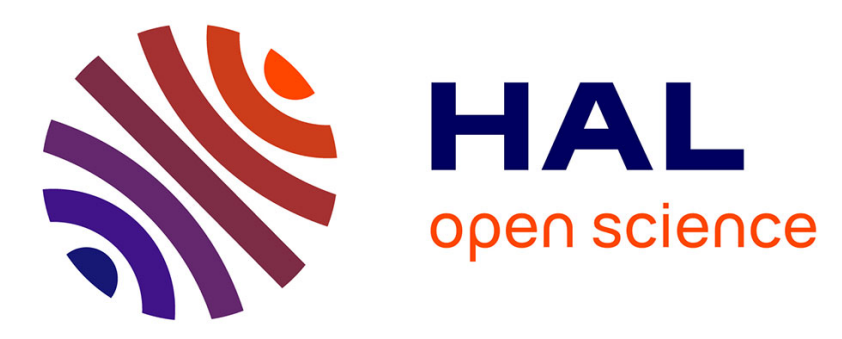

\title{
Imaging strain localisation in porous andesite using digital volume correlation
}

Michael J. Heap, Patrick Baud, Jessica A. Mcbeck, Francois Renard, Lucille Carbillet, Stephan A. Hall

\section{- To cite this version:}

Michael J. Heap, Patrick Baud, Jessica A. Mcbeck, Francois Renard, Lucille Carbillet, et al.. Imaging strain localisation in porous andesite using digital volume correlation. Journal of Volcanology and Geothermal Research, 2020, 404, pp.107038. 10.1016/j.jvolgeores.2020.107038 . insu-03094752

\section{HAL Id: insu-03094752 \\ https://hal-insu.archives-ouvertes.fr/insu-03094752}

Submitted on 4 Jan 2021

HAL is a multi-disciplinary open access archive for the deposit and dissemination of scientific research documents, whether they are published or not. The documents may come from teaching and research institutions in France or abroad, or from public or private research centers.
L'archive ouverte pluridisciplinaire HAL, est destinée au dépôt et à la diffusion de documents scientifiques de niveau recherche, publiés ou non, émanant des établissements d'enseignement et de recherche français ou étrangers, des laboratoires publics ou privés. 


\section{Journal Pre-proof}

Imaging strain localisation in porous andesite using digital volume correlation

Michael J. Heap, Patrick Baud, Jessica A. McBeck, François Renard, Lucille Carbillet, Stephan A. Hall

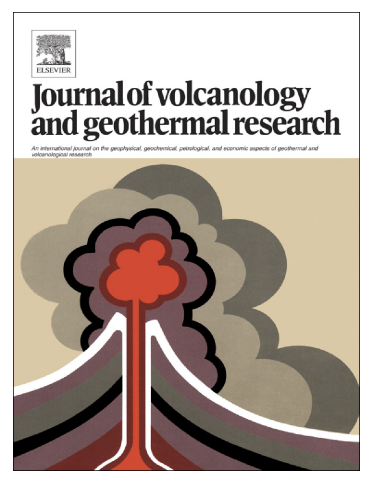

PII: $\quad$ S0377-0273(20)30330-9

DOI: $\quad$ https://doi.org/10.1016/j.jvolgeores.2020.107038

Reference: $\quad$ VOLGEO 107038

To appear in: Journal of Volcanology and Geothermal Research

Received date: $\quad 10$ June 2020

Revised date: $\quad 19$ August 2020

Accepted date: 21 August 2020

Please cite this article as: M.J. Heap, P. Baud, J.A. McBeck, et al., Imaging strain localisation in porous andesite using digital volume correlation, Journal of Volcanology and Geothermal Research (2020), https://doi.org/10.1016/j.jvolgeores.2020.107038

This is a PDF file of an article that has undergone enhancements after acceptance, such as the addition of a cover page and metadata, and formatting for readability, but it is not yet the definitive version of record. This version will undergo additional copyediting, typesetting and review before it is published in its final form, but we are providing this version to give early visibility of the article. Please note that, during the production process, errors may be discovered which could affect the content, and all legal disclaimers that apply to the journal pertain.

(C) 2020 Published by Elsevier. 
Imaging strain localisation in porous andesite using digital volume correlation

Michael J. Heap ${ }^{1}$, Patrick Baud ${ }^{1}$, Jessica A. McBeck ${ }^{2}$, François Renard ${ }^{2,3}$, Lucille Carbillet $^{1}$, and Stephan A. Hall ${ }^{4,5}$

${ }^{1}$ Géophysique Expérimentale, Institut de Physique de Globe te Strasbourg (UMR 7516 CNRS, Université de Strasbourg/EOST), 5 rue René Descu.to, 67084 Strasbourg cedex, France

${ }^{2}$ Physics of Geological Processes, The Njord Centre, De , artment of Geosciences, University of Oslo, Norway

${ }^{3}$ Université Grenoble Alpes, Université 'av ie ıront Blanc, CNRS, IRD, IFSTTAR, ISTerre, 38000 Grenoble, France

${ }^{4}$ Division of Solid Mechanics, Lund 'J iil r rsity, Lund 22100, Sweden

${ }^{5}$ Lund Institute for advanced N'em.'ron and X-ray Science (LINXS), Scheelevägen 19, 22370 Lund, Sweden

*Corresponding author. :rlichael Heap (heap@unistra.fr)

\section{Highlights}

- Shear fractures associated with localised dilation and permeability increase.

- Compaction bands associated with localised compaction and permeability decrease.

- Compaction bands form in the most porous part of the sample, within the wellconnected porosity backbone. 
- Geometric characteristics of compaction bands in lavas likely related to pore size and structure.

- Digital volume correlation is a useful tool to study strain localisation in porous volcanic rocks.

\section{Abstract}

Strain localisation structures, such as shear fractures and compaction bands, are of importance due to their influence on permeability and therefr.: outgassing, a factor thought to influence eruptive style. In this study, we aim to deve' op . better understanding of strain localisation in porous volcanic rocks using X-ray tom $\sigma_{1}$. phic images of samples of porous andesite (porosity $=0.26$ ) acquired before and aft $r$ a formation in the brittle and ductile regimes. These $3 \mathrm{D}$ images have been first a $\mathrm{a}_{\mathrm{t}^{\prime}}{ } \mathrm{d}$ d to provide $3 \mathrm{D}$ images of the porosity structure within the undeformed andesit, $r$, hich consists of a large, well-connected porosity backbone alongside many smaller pore that are either isolated or connected to the porosity backbone by thin microstructur. 't:ments (e.g., microcracks). Following deformation, porosity profiles of the sample. show localised dilation (porosity increase) and compaction (porosity reduction) within the samples deformed in the brittle and ductile regimes, respectively. Digital $v^{\prime}{ }^{1} \mathrm{l} m e$ correlation (DVC) of the images before and after triaxial deformation was used to quantify the tensor strain fields, and the incremental divergence (volumetric strain) and curl (used as an indicator of shear strain) of the displacement fields were calculated from the DVC. These fields show that strain localisation in the sample deformed in the brittle regime manifested as a $\sim 1 \mathrm{~mm}$-wide, dilatational shear fracture oriented at an angle of $40-45^{\circ}$ to the maximum principal stress. Pre- and post-deformation permeability measurements show that permeability of the sample deformed in the brittle regime increased from $3.9 \times 10^{-12}$ to $4.9 \times 10^{-12} \mathrm{~m}^{2}$, which is presumed to be related to the 
shear fracture. For the sample deformed in the ductile regime, strain localised into $\sim 1 \mathrm{~mm}$ thick, undulating compaction bands orientated sub-perpendicular to the maximum principal stress with little evidence of shear. Taken together, our data suggest that these bands formed during large stress drops seen in the mechanical data, within high-porosity zones within the sample, and within the large, well-connected porosity backbone. Pre- and post-deformation permeability measurements indicate that inelastic compaction decreased the permeability of the sample by a factor of $\sim 3$. The data of this study assist in the understanding of strain localisation in porous volcanic rocks, its influence on permenhilıy (and therefore volcanic outgassing), and highlight an important role for DVC in studying strain localisation in volcanic materials.

Keywords: andesite; fracture; compaction bald, ne.meability; X-ray computed tomography; digital image correlation

\section{Introduction}

Evidence for the locali ation of strain in volcanoes and volcanic rocks is abundant. Lava domes contain abundaı+' ractures (e.g., Anderson and Fink, 1990; Watts et al., 2002; Hale and Wadge, 2008, Buı et al., 2013; Darmawan et al., 2018). An impressive example of a lava dome fracture is the $200 \mathrm{~m}$-long and $40 \mathrm{~m}$-wide fracture that formed within the dome at Merapi volcano (Indonesia) following an explosion in 2013 (Walter et al., 2015). Lava spines are extruded along gouge rich conduit-margin faults (e.g., Iverson et al., 2006; Cashman et al., 2008; Kennedy and Russell, 2012; Hornby et al., 2015; Lamb et al., 2015; Ryan et al., 2018, 2020). The spines extruded at Mt St Helens (USA) from 2004 to 2008, for example, were mantled by a 1-3 m-thick layer of cataclasites, breccias, and gouge (e.g., Cashman et al., 2008). Ash-filled fractures within conduits and lava domes-called 
tuffisites - record episodes of brittle deformation, magma fragmentation, and outgassing (e.g., Tuffen et al., 2003; Castro et al., 2014; Saubin et al., 2016; Farquharson et al., 2016a; Gardner et al., 2018; Heap et al., 2019a). Faults are also commonly observed in sequences of volcanic rock (e.g., Gudmundsson, 2011; Holland et al., 2006; Walker et al., 2013; Bubeck et al., 2018) and localised compaction features have been observed in outcrops of tuff (e.g., Wilson et al., 2003; Okubo, 2014; Cavailhes and Rotevatn, 2018). Furthermore, volcanic rocks can contain flow bands, defined by differences in the abundance and/or preferred orientation of crystals and/or pores (e.g., Tuffen et al., 2003; ' 2005; Gonnermann and Manga, 2005), that form as mi gnı's deform on their way to the surface.

Strain localisation also plays an importari $1^{1} \mathrm{e}$ in governing the behaviour of volcanoes. For example, the permeability of a $\sqrt{ }$ ic edifice is thought to exert control over whether a volcano erupts effusively or $\epsilon^{-n l}$ ssively (e.g., Eichelberger et al., 1986; Mueller et al., 2008; Cassidy et al., 2018) and cractures can serve to increase the permeability of volcanic rock (e.g., Nara et al., 2n11, valker et al., 2013; Farquharson et al., 2016b; Heap and Kennedy, 2016). Strain lo 'lisation can also negatively influence the stability of volcanic structures (e.g., Voight, 2n心: ' Lagmay et al., 2000), the collapse of which can result in the formation of destructiv anu deadly pyroclastic density currents (e.g., Glicken, 1996; Cole et al., 1998; Komorowski et al., 2013).

The failure mode of volcanic rock (i.e. volcanic materials below their glass transition threshold) depends, to a first order, on the confining pressure (i.e. depth) and the porosity of the rock: low pressure and low porosity favour brittle deformation and high pressure and high porosity favour shear-enhanced compaction (e.g., Zhu et al., 2011; Heap et al., 2015a). Although temperature can affect the mechanical behaviour of volcanic materials below their glass transition threshold, fully- or almost-fully-crystallised lavas were still brittle at high 
temperature (700-950 ${ }^{\circ} \mathrm{C}$; Benson et al., 2012; Heap et al., 2018). In volcanic rocks, strain localises into shear and tensile fractures in the brittle regime (e.g., Benson et al., 2007; Heap and Kennedy, 2016; Zhu et al., 2016). At relatively high effective pressures, laboratory studies have shown that inelastic compaction in volcanic rocks can either be distributed, termed "cataclastic flow" (e.g., Zhu et al., 2011), or localised into bands (e.g., Loaiza et al., 2012; Adelinet et al., 2013; Heap et al., 2015a). Both cataclastic flow and the formation of compaction bands, planar deformation features characterised by a lower porosity than the surrounding host rock, are often considered as ductile beharin ${ }^{-r}$ Laboratory experiments have shown that shear (Fortin et al., 2011; Walker et al., 2'sı, Farquharson et al., 2016b) and tensile fractures (e.g., Nara et al., 2011; Heap and Kann ty, 2016; Eggertsson et al., 2020) involve dilatancy and can increase the permeabilit $y \iota^{f}$ volcanic rock by many orders of magnitude. Rare studies on the influence of naction bands on the permeability of volcanic rock have shown that they ca. $d$-crease sample permeability by up to about one order of magnitude (Heap et al., 2015a, Garquharson et al., 2017).

Microstructural analysis in 1, h sratory-deformed samples have highlighted that the dilatant fracture of volcanic ru ks mivolves a complex interplay between microcracks, pores, and phenocrysts (e.g., Zhil :t al., 2016). Fractures are seen to emanate from pores and propagate through both ¿roundmass and phenocrysts (e.g., Zhu et al., 2011; Heap et al., 2014; Heap et al., 2015a; Zhu et al., 2016; Coats et al., 2018). Tensile fractures in andesite were found to be more tortuous as a function of increasing porosity (Heap and Kennedy, 2016). Benson et al. (2007) imaged the growth of a shear fracture in a low-porosity basalt from Mt Etna (Italy) by locating acoustic emissions (i.e. microcrack formation and growth; Lockner, 1993) within the sample during deformation. These authors found that the fracture, which formed an inclined plane within the sample, propagated from the lower right-hand to the

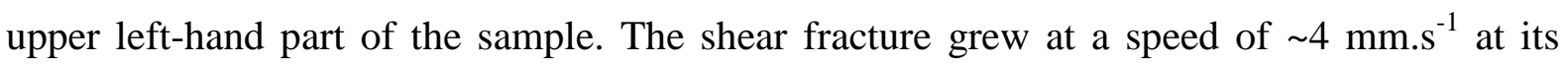


leading edge and $\sim 2 \mathrm{~mm} . \mathrm{s}^{-1}$ at its centre; this is considerably slower than the shear fracture growth speed for granite (Benson et al., 2007). McBeck et al. (2019) studied shear fracture formation in the same low-porosity basalt using digital volume correlation (DVC) techniques and found that the strain localisation process started before the peak stress and was proceeded by phase of compaction. However, studies aimed at studying strain localisation in the brittle regime in porous volcanic rocks using techniques other than microscopy are currently absent.

Compared to our understanding of compaction band formation in porous sedimentary rocks, our understanding of this process in volcanic rocks is - mb.yonic. Compaction bands were first documented in sandstone (Hill, 1989; Mollema anc Antonellini, 1996) and later in carbonate (Cilona et al., 2014; Rotevatn et al., 201h) `ormations. Field, laboratory, and

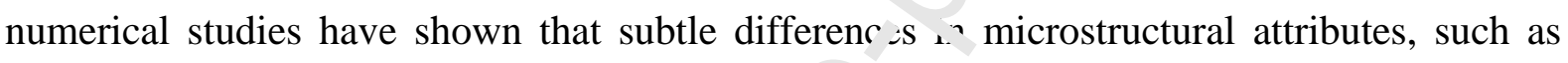
grain size distribution, can promote or inhi'ji, th $\leftarrow$ development of compaction bands in granular materials (Wang et al., 2008; $\mathrm{T}$, ung et al., 2012). Compaction bands formed in laboratory deformation experiments typ: ally have a thickness of 2-4 grains, are oriented subperpendicular to the maximum Prit. $^{\circ}$ pal stress, initiate at one side of the sample and propagate to the other, are assc iated with intense grain crushing and pore collapse, and their growth is marked by an untı.' 'n acoustic emission activity (e.g., Baud et al., 2004; Louis et al., 2006; Fortin et al., 2nuo; Townend et al., 2008; Charalampidou et al., 2011; Heap et al., 2015b; Baud et al., 2015; Huang et al., 2019; Shahin et al., 2019). Compaction bands have also been found in porous tuffs (Cavailhes and Rotevatn, 2018) and laboratory studies on volcanic rocks have, so far, observed compaction bands in porous basalt (Adelinet et al., 2013), porous trachyandesite (Loaiza et al., 2012), porous andesite (Heap et al., 2015a, 2017), and porous dacite (Heap et al., 2016). The compaction bands observed in these laboratory studies on volcanic rocks have shown some geometric similarities with those observed in sedimentary rocks. However, because the studied rocks were all lavas (i.e. non-granular), the 
compaction bands formed in these samples were planes of collapsed pores connected by microcracks that formed sub-perpendicular to the maximum principal stress. It is likely therefore that the geometry of compaction bands in volcanic rock depends on the distribution of pores within the sample (as discussed in Heap et al., 2015a).

In this study, we selected a porous andesite from Volcán de Colima (Mexico) for which extensive sets of petrophysical and mechanical data were recently published (e.g., Heap et al., 2017). We first used X-ray Computed Tomography (CT) to detail the complexity of the void space within the andesite. CT has been used to ${ }^{n+1} d y$ the topology of the pore space of simple rocks such as Fontainebleau sandstone (Lı'dquist et al., 2000) and more microstructurally complex porous rocks (e.g., Bauer e+ ^l., ?012; Fusseis et al., 2012; Ji et al., 2012; Kandula et al., 2019). The microstructure of 1 dVa. (e.g., Song et al., 2001; Jamtveit et al., 2011, 2014; Pola et al., 2012; Bubeck (t . 1 2017; Schipper et al., 2017) and highporosity (> 0.5) scoria and pumice (e.s rolacci et al., 2006; Zandomeneghi et al., 2010; Degruyter et al., 2010; Baker et al., 20:1; Voltolini et al., 2011; Giachetti et al., 2011; Pardo et al., 2014) have been studied ving $\boldsymbol{r}_{\text {-T }}$. CT has also been used to study porosity loss by viscous sintering in granular ^. aterials in volcanic systems (Wadsworth et al., 2017, 2019) and particle size and shape in $\cdots$ ifisites (Black et al., 2016).

In this work, ou man objective is to use 3D CT image data to better understand the development of strain localisation in andesite deformed in the brittle and ductile regimes. Brittle and ductile are used herein to describe the deformation on the lengthscale of a laboratory sample. Brittle deformation is synonymous with the formation of a macroscopic shear fracture and, although ductile deformation typically "describes the capacity of a material to deform to substantial strain without the tendency to localise the flow into bands (faults)" (Rutter, 1986), this simple definition is complicated by instances of compaction localisation in the ductile regime (Wong and Baud, 2012). Here, samples that contain 
compaction localisation are considered ductile. Our concept of ductility does not depend on the micromechanisms of deformation and, therefore, ductility in volcanic materials is not restricted to viscous flow.

Previous studies showed that CT imaging, even with limited resolution, could reveal shear bands in laboratory deformed sandstone (see, for example, Bésuelle et al., 2003). However, imaging failure in complex rocks such as shales or compaction localisation in sandstone typically requires image analysis (e.g., Louis et al. 2006; Lenoir et al., 2007). For example, digital image correlation techniques were used to jreresigate strain localisation in sedimentary rocks (e.g., Louis et al., 2007; Charalampido ^ eı al., 2010; Dautriat et al., 2011; Ji et al., 2015; Tudisco et al., 2015; McBeck et al., 2018; ?enard et al., 2017, 2019; McBeck et al., 2020). Recently, digital volume correlation (JV $:$ ) was used to study failure in lowporosity basalt from Mt Etna using in situ X- $a$ a $s$ nchrotron microtomography (McBeck et al., 2019). However, such high-resolutiv' i naging $(6.5 \mu \mathrm{m} / \mathrm{voxel})$ can only be performed on very small samples (the sample deformt ${ }^{\wedge}$ in the study of McBeck et al. (2019) was a $3.7 \mathrm{~mm}$ diameter cylinder) and therefore : " 1 - suited to capture porosity development in the vast majority of porous volcanic ro' ${ }^{1} \mathrm{~s}$, which often contain pores above $1 \mathrm{~mm}$ in diameter (e.g., Shea et al., 2010; Heap at ai., 2014). Here, we perform DVC on X-ray images of porous andesite deformed in bu'h the brittle and ductile regimes to study the development of shear fractures and compaction bands in porous volcanic rock. To avoid issues with large pores, we used a standard laboratory sample size (20 mm-diameter cylinders) and therefore a lower imaging resolution (23 $\mu \mathrm{m} /$ voxel) than McBeck et al. (2019).

\section{Material characterisation and methods}

The block of andesite used for this study was collected from within a debris-flow track ("La Lumbre") on the flanks of Volcán de Colima (Mexico; Figure 1a). Volcán de 
Colima is an active andesitic stratovolcano located in the Trans-Mexican Volcanic Belt (Varley et al., 2019; Figure 1a). This block of andesite is the same as that used for the study of Heap et al. (2017), and similar to those used in recent uniaxial and triaxial deformation studies (Lavallée et al., 2013; Kendrick et al., 2013; Heap et al., 2014, 2015a). Heap et al. (2017) showed the brittle-ductile transition for the studied andesite occurs at an effective pressure (confining pressure minus the pore fluid pressure) between 20 and $30 \mathrm{MPa}$ and that it forms compaction bands when deformed at high pressure, and so it is an ideal material for this study. The andesite has a porphyritic texture that contains ${ }_{1}$ he ${ }_{1}$. pyroxene and irregularly-shaped pores (with radii from a co nle of tens of microns to $\sim 500$ $\mu \mathrm{m}$ ) within a glassy groundmass (that contains abund nnt . nicrolites, mainly plagioclase with subordinate high-density Fe-Ti oxides) (Figure $1 \mathrm{~b}$ how:s a backscattered scanning electron microscope (SEM) image). The volume fraction $\approx f$ phenocrysts is $\sim 0.4$ and the groundmass consists of microlite and glass volume $1^{\prime}{ }^{\prime}$, cions of $\sim 0.2$ and $\sim 0.135$, respectively (Heap et al., 2017). The andesite also contains abı ndant microcracks (Figure 1b).

Two cylindrical samples. $27 \mathrm{~mm}$ in diameter and $40 \mathrm{~mm}$ in length, were prepared

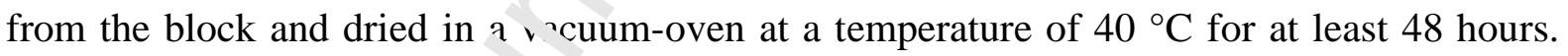
The connected porosity $r^{\kappa}$ thud samples was then calculated using the bulk sample volume and the skeletal volun ' measured by a helium pycnometer. Their total porosity was calculated using the skeletal density of the block (calculated using the mass and volume, measured using the pycnometer, of a powdered aliquot of the block) and the bulk sample density. The permeability of the two samples was then measured under a confining pressure of $1 \mathrm{MPa}$ using a benchtop gas (nitrogen) permeameter (see Heap and Kennedy, 2016). The samples were first left at $1 \mathrm{MPa}$ for 1 hour to ensure microstructural equilibrium. Volumetric flow rates (measured using a gas flowmeter) were then measured for six pore pressure 
differentials (measured using a pore pressure transducer) to calculate permeability using Darcy's law and to check if Forchheimer or Klinkenberg corrections were required.

X-ray tomography images were made of the samples at the 4D Imaging Laboratory at Lund University (Sweden) using a ZEISS Xradia 520 Versa 3D X-ray microscope. Tomography, with cubic voxels of side length $23 \mu \mathrm{m}$, were acquired before and after triaxial deformation. Figure 2 presents a 2D vertical slice extracted from the 3D image volume of sample LL3, which shows the features (pores and phenocrysts) observed in the SEM image (Figure 1b). Figure 2 also shows a histogram of the X-ray att slaion coefficient for the CT image volume as a function of grey level, where 0 (lo vesı attenuation) and 255 (highest attenuation) correspond to black and white, respective 1 . and $\sim 63$ correspond to the porosity (macropores) and he glassy groundmass, respectively (Figure 2). Values of grey level above that of $\ldots$ - groundmass $(>\sim 80)$ correspond to the denser plagioclase phenocrysts and $\mathrm{Va}^{\prime}{ }^{\prime} \mathrm{w} / \mathrm{s}$ of grey level between the two main peaks correspond to pixels that contain both $g_{1}$ गundmass and porosity (microporosity) (Figure 2). If we segment the images (porosity . as a...ken as all the voxels with a grey level lower than the minimum following the first $\mathrm{r}^{\mathrm{a}} \mathrm{ak}$ in $\mathrm{X}$-ray attenuation (corresponding to the macropores) within the sample, as indinate 1 in Figure 2), a 3D image of the porosity structure can also be generated (Figure 3). The 3D images in Figure 3 were prepared using Avizo® Fire 3D visualisation and analysis software. Figure 3a shows a 3D image that highlights all of the porosity (each connected pore is shown in a different colour) within one of the samples (sample LL3). The large, dark blue-coloured pore represents the well-connected porosity backbone of the sample (Figure 3a). The pores unconnected to this backbone, or connected to the porosity backbone by very thin microstructural elements (e.g., microcracks) that have a size below the scanning resolution, are best observed when this large, well-connected connected pore is removed from the image (Figure $3 b$ ). The porosity structure of the porous 
andesite studied can, therefore, be considered to consist of a large, well-connected porosity backbone alongside many smaller pores that are either isolated or connected to the porosity backbone by very thin microstructural elements (e.g., microcracks) (Figure 3). Figure 3c shows the equivalent pore radius distribution for these isolated or poorly-connected pores. We measure no pores with a radius below $75 \mu \mathrm{m}$, which is likely a function of the voxel size (23 $\mu \mathrm{m} /$ voxel). Indeed, pores with a radius $<75 \mu \mathrm{m}$ are seen in the SEM image of the studied material (Figure 1b). The majority of the isolated or poorly-connected pores detected in the X-ray images have a radius between 100 and $200 \mu \mathrm{m}$ (Figure $x$, and the average pore radius is $126 \mu \mathrm{m}$.

Prior to deformation in the triaxial press, pe ron ned at the University of Strasbourg (France), both samples were vacuum-saturated in reionised water and wrapped in a thin $(<<$ $1 \mathrm{~mm}$ ) copper jacket. The thin copper jackit hesps to protect the integrity of the sample during unloading, but does not influence the mechanical behaviour of the sample during deformation. The samples were ins ${ }^{+}+e a$ into a Viton ${ }^{\circledR}$ rubber sleeve and placed inside the pressure vessel. The confining tnc nore fluid pressure were then slowly increased using servo-controlled confining . na nore fluid pressure pumps, respectively, to the chosen pressure (either 20 or $6 \mathrm{~J}, \mathrm{Ta}$ for the confining pressure and $10 \mathrm{MPa}$ for the pore fluid pressure). We assume he ein a simple effective pressure law where the effective pressure is equal to the confining pressure minus the pore fluid pressure. The samples were then left overnight at the target effective pressure to ensure microstructural equilibration. The samples were subsequently deformed in compression at an axial strain rate of $10^{-5} \mathrm{~s}^{-1}$. During deformation we recorded axial load and displacement, which were converted to axial stress and strain using the sample dimensions, and the change in sample porosity (monitored by the pore fluid pump). We note that measured values of axial stress and strain and porosity correspond to bulk sample measurements. During deformation, the confining and pore fluids 
pressures were held constant by the servo-controlled pumps. Sample drainage during deformation was ensured by the high permeability of the studied material $\left(>10^{-12} \mathrm{~m}^{2}\right.$; Heap and Wadsworth, 2016). The sample deformed at an effective pressure of $10 \mathrm{MPa}$ was unloaded at a strain rate of $10^{-5} \mathrm{~s}^{-1}$ immediately following the large stress drop typically associated with the formation of a macroscopic shear fracture. The sample deformed at an effective pressure of $50 \mathrm{MPa}$ was unloaded following deformation to an axial strain of 0.015 . These samples were then dried completely in a vacuum-oven and re-scanned, as described above. The sample deformed at an effective pressure of $\sigma_{v}$ Mra was then re-saturated, deformed again at the same conditions to an axial strain if 0.915 , carefully unloaded, dried, and then scanned a third time. Finally, the permear ${ }_{i 1}+v$ of the deformed samples was remeasured using the above-described method. Both Jur ᄂ iaxial deformation experiments and permeability measurements were performed $u^{\prime} d_{1}$ umbient laboratory temperatures.

The magnitude and spatial disı ${ }^{2}$ ation of the volumetric and distortional strain components were calculated using the InmoWarp2 DVC code (Tudisco et al., 2017) using the tomography images acquirer: :elure and after deformation. Using these displacement fields, we calculated divergerse and curl fields using by matching voxel constellations between the sequential $\mathrm{Y}_{-1 n y}$ image acquisitions. Negative and positive divergence corresponds to compac ion and dilation, respectively, and negative and positive curl corresponds to left-lateral and right-lateral rotations, respectively, indicative of shear strain. We used Moran's I coefficient (Moran, 1948) to determine the spatial localisation of the incremental strain populations (e.g., Zhang and Lin, 2016; Thompson et al., 2018; McBeck et al., 2019). We refer the reader to Tudisco et al. (2017) and McBeck et al. (2019) for more information on the DVC technique used here.

\section{Results}




\subsection{Porosity and permeability data}

The connected porosities, measured by the pycnometer, of samples LL5 and LL3 were 0.256 and 0.262 , respectively. The skeletal density of the block was measured to be $2669 \mathrm{~kg} / \mathrm{m}^{3}$, which yields total porosities for LL5 and LL3 of 0.261 and 0.269 , respectively, and isolated porosities of 0.006 and 0.005 , respectively. The intact permeabilities of samples LL5 and LL3 were $3.9 \times 10^{-12}$ and $4.7 \times 10^{-12} \mathrm{~m}^{2}$, respectively. Following deformation, the permeabilities of samples LL5 and LL3 were $4.9 \times 10^{-12}$ and $1 . . \times 10^{-12} \mathrm{~m}^{2}$, respectively.

\subsection{Mechanical data}

The stress-strain curves and porosity reduc ion zurves for both samples (LL5 and LL3) are shown in Figure 4. The mechanica daim for the sample deformed at an effective pressure of $10 \mathrm{MPa}$ (LL5) are typical $\iota^{-*}$ a rock sample deforming in compression in the brittle regime (e.g., Brace et al., 1966 \ s holz, 1968). Differential stress is first a non-linearly increasing function of axial strair, $\mathrm{ftun}$ attributed to the closure of pre-existing microcracks, followed by a quasi-linear ela ${ }^{+i c}$ stage. Differential stress is then non-linearly increasing function of axial strain, $\cdots$ ibued to the formation and growth of microcracks (i.e. inelastic deformation). A peak Su ss can be observed in the stress-strain data at $\sim 93 \mathrm{MPa}$, which is followed by a stress drop (Figure 4a). It is during this stress drop that microcracks coalesce to form a macroscopic fracture. The porosity data show that the rock first compacted, the rate of which slowed above the stress required for the formation and propagation of microcracks, termed $C^{\prime}$ (at $\sim 30 \mathrm{MPa}$; Figure $4 \mathrm{c}$ ). Compaction and dilation were balanced at a differential stress of $\sim 70-80 \mathrm{MPa}$ (corresponding to an axial strain of $\sim 0.005$ and a porosity decrease of 0.0025). Above this stress, the rock entered a phase of net dilation (Figure 4c). Porosity was increased by 0.001 during this phase and, at the end of the loading part of the experiment, the 
porosity of the sample had been reduced by 0.0015 (Figure 4c). The porosity of the sample decreased during the unloading part of the experiment and the final porosity change of the sample (i.e. at the point of the second scan) was a reduction of 0.0021 (Figure 4c).

The mechanical data for the sample deformed at an effective pressure of $50 \mathrm{MPa}$ are typical for porous andesite deforming in compression in the ductile regime (e.g., Heap et al., 2015a; Heap et al., 2017). Indeed, previous experimental studies that the stress-strain curves of lava deforming in the ductile regime can be punctuated by stress drops, considered to be associated with the formation of compaction bands (e.g., Heэn el al., 2015a, 2017). A large stress drop (> $70 \mathrm{MPa}$ ) can be seen in the stress-strain $r$ ata tor the first loading-unloading experiment, after which the stress increases (Figure 4h) The porosity data show that the rock compacted throughout the experiment (Figure 4d). it ise end of the first loading-unloading experiment (i.e. at the point of the second sca $\mathrm{i}$, $\mathrm{h} f$ porosity of the sample had been reduced by 0.01 (Figure 4d). During the second, ar. Ing-unloading experiment, we note another large stress drop during the loading stage, or about $40 \mathrm{MPa}$ (Figure $4 \mathrm{~b}$ ). At the end of the second loading-unloading experiment ( $\mathrm{i}$ a he point of the third scan), the sample had lost a porosity of 0.019 (Figure 4d).

\subsection{Porosity profiles be ire $^{2}$ and after deformation}

Figure 5 shows porosity profiles along the length of the samples deformed in the brittle (LL5) and ductile (LL3) regimes before and after deformation. The porosity was taken as all the voxels with a grey level lower than the minimum following the first peak in X-ray attenuation (corresponding to the macropores) within the sample (indicated in Figure 2). Although this approach underestimates the porosity, as micropores smaller than the voxel size are not captured, it provides data for the intact and deformed samples that can be confidently compared. The sample edges were excluded from this analysis. 
The porosity profiles of the sample deformed in the brittle regime show that, following deformation, the porosity of the sample notably increased (by almost 0.01 ) between a distance of $\sim 25$ to $\sim 30 \mathrm{~mm}$ along the sample length (Figure 5a). The average porosity of the sample determined using this technique increased from 0.128 to 0.130 following deformation. The porosity profiles for the sample deformed in the ductile regime show that, following the first round of deformation (see Figure 4c), the porosity of the sample was largely unchanged (Figure 5b). The average porosity of the sample increased slightly following the first round of deformation, from 0.150 to 0.153 . By contrast, the mechanic ${ }^{-1}$ dain indicate that the sample was compacting during this stage (Figure 4d). Following th second round of deformation, the porosity between a distance of $\sim 25$ to $\sim 33 \mathrm{~mm}$ along li. sample length decreased by up to 0.04 , and the average porosity of the sample decrea ea from 0.153 to 0.147 (Figure $5 b$ ). As discussed above, this method underestimates $t_{1} \cdot$; microporosity. For example, the connec $\downarrow$ ', orosity of LL5 and LL3 prior to deformation was measured using the pycnometer to be 0.256 and 0.262 , respectively.

\subsection{Digital volume correlation ; TVL)}

The strain fields den ${ }_{1}$ from the DVC are presented in Figure 6, as vertical slices through the 3D volumc. or divergence (volumetric strain) and curl magnitude (a proxy for shear strain). The DVC for the sample deformed in the brittle regime (LL5) shows clear evidence of strain localisation (Figure 6a). The feature, orientated at an angle of $40-45^{\circ}$ to the maximum principal stress with a width of $\sim 1 \mathrm{~mm}$, is a planar volume characterised by elevated dilation and shear (Figure 6a). The remainder of the sample (i.e. outside the localisation feature) is characterised by dilation and low shear (apart from the bottom left and top right of the sample) (Figure 6a). The first loading-unloading experiment in the ductile regime does not show any clear localisation features (Figure 6b). In contrast to the 
mechanical data, which show that the sample experienced compaction (Figure 4d), the DVC maps show that the sample is characterised by distributed dilation and low shear strain (Figure 6b). The second loading-unloading experiment in the ductile regime shows clear evidence for strain localisation (Figure 6c). The feature, orientated sub-perpendicular to the maximum principal stress with a thickness of $\sim 1 \mathrm{~mm}$, is a planar volume characterised by compaction and very little shear (Figure 6c). The remainder of the sample (i.e. outside the localisation feature) is characterised by compaction (apart from the bottom left of the sample and adjacent to the compaction feature) and high shear (Figure $a_{c}$ ).

\section{Discussion}

Based on their geometrical attributes, we int $\operatorname{rp}_{\mathbf{t}}$ the inclined dilatational plane and the sub-horizontal compaction plane in the brtt. $\cdot$.ld ductile regimes as a dilatational shear band and a compaction band, respective ${ }_{2}$;

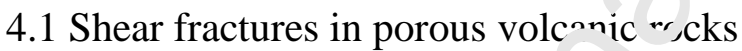

The shear fracture with. $\urcorner$ the porous andesite sample is oriented at an angle of $40-45^{\circ}$ to the maximum principal sws (Figure 6a), formed within a high-porosity zone of the sample (Figure 5a), has ^ w1dth of $\sim 1 \mathrm{~mm}$ (Figure $6 \mathrm{a}$ ), and is characterised by an increase in porosity (Figure 5a and Figure 6a). Our permeability data show that the permeability of the sample was higher after deformation, which we attribute to the shear fracture.

Shear fracture formation in low-porosity rocks, such as granite, results in dilation and large increases to sample permeability (e.g., Mitchell and Faulkner, 2008). Shear bands in high-porosity sandstone, however, can either be dilatant or compactant (e.g., Bésuelle, 2001). Laboratory studies have shown that both dilatant and compactant shear bands reduce the permeability of porous sandstone (e.g., Zhu and Wong, 1997). Laboratory studies have also 
shown that shear fractures in basalt and andesite can increase sample permeability by three orders of magnitude (Farquharson et al., 2016b); however, the experiments of Farquharson et al. (2016b) were restricted to samples with initial porosities $<0.15$. Experiments on sandstones show that decreases to sample permeability are seen following brittle failure when the initial porosity is $>0.15$, interpreted as a result of a dramatic increase in void space tortuosity due to microcracking (Zhu and Wong, 1997). However, it was unclear whether a porous volcanic rock (porosity $>0.15$ ), with a microstructure characterised by an amorphous glassy groundmass that hosts pores (compared to the granuln $n_{i}$ zrostructure presented by sandstone), would also exhibit a decrease in sample per nt bility following brittle failure. Our new data show that a shear fracture that formed in $a_{1}$ andesite with an initial porosity of $\sim 0.26$ at low effective pressure was associated with loc. lised dilation (i.e. porosity increase) on the fracture (Figures 5a and 6a) and a $n+t$ nr.ease in porosity throughout the sample (Figure 6a). A small increase in sample ${ }_{\uparrow}$ er neability (from $3.9 \times 10^{-12}$ to $4.9 \times 10^{-12} \mathrm{~m}^{2}$ ) was also observed following the formatio. of a dilatant shear fracture. This relatively small increase is considered to be the $\backsim n^{\prime} \backsim$ dence of the high initial permeability of the sample: fractures in laboratory sample. exert a much greater influence on the permeability of lowporosity, low-permeability $w_{\text {anic }}$ rocks (e.g., Heap and Kennedy, 2016). We note that compactional shear ban. ${ }^{1} s$ may form in the studied andesite at higher effective pressures, but below the pressure required for the brittle-ductile transition (between 20 and $30 \mathrm{MPa}$; Heap et al., 2017), which may result in reductions to sample permeability. Systematic laboratory experiments are now required to investigate the influence of shear bands (both dilational, as studied here, and compactional shear bands that form at higher effective pressures) on the permeability of porous volcanic rocks.

4.2 Compaction bands in porous volcanic rocks 
Our porosity analysis data (Figure 5b) and DVC data (Figure 6b) show that there was a net increase in porosity following the first round of deformation in the ductile regime. These data are in conflict with our mechanical data, which show that the sample compacted during deformation (Figure 4d). The reason for this discrepancy is because the compaction band that formed following the first round of deformation was located at the top of the sample (Figure 7) and was therefore not included in the porosity (Figure 5b) or DVC analyses (Figure 6b). During the second round of deformation, however, we see clear evidence for a compaction band in both the porosity data (Figure 5b) and the LVC analyses (Figure 6c). There are, therefore, two compaction bands in the sam sle following the second loadingunloading experiment. The formation of these compart 1 ? bands likely occurred during the two large stress drops (associated with porosity redution) seen in the mechanical data (Figures $4 \mathrm{~b}$ and $4 \mathrm{~d}$ ), as previously observed $\mathrm{d} \mathrm{r}_{\mathrm{n}} \cdot \mathbf{\sigma}$. ompaction band formation in sandstones (Baud et al., 2004). The stress drops see. in our mechanical data (Figure 4b) are therefore the result of the formation of bands of collansed pores within the sample. This hypothesis is also supported by the fact that the $\mathrm{cr} \sim \mathrm{p}_{\mathrm{c}}$. ion band formed during the first loading-unloading cycle did not increase in thickı. 'ss tollowing the second round of deformation.

The average thicknes ' of the compaction band formed during the second round of deformation (imaged $\mathrm{w}^{\cdot}$ th the porosity and DVC analysis) is $\sim 1 \mathrm{~mm}$ (Figure $6 \mathrm{c}$ ) and, as a result of its undulating geometry (the tortuosity of the band in the slice shown in Figure $6 \mathrm{c}$ is 1.48), affects a zone that is $\sim 8 \mathrm{~mm}$ wide (Figure $5 \mathrm{~b}$; Figure $6 \mathrm{c}$ ). The porosity profile data show that this compaction band formed within the most porous part of the sample (Figure $5 b)$. We further note that the number of isolated or poorly-connected pores in the sample following the second round of deformation, and their average radius and radius distribution, were very similar to the undeformed sample. For example, the average pore radius was 126 
$\mu \mathrm{m}$ in both cases. These data suggest that the compaction band formed within the large, wellconnected porosity backbone of the sample (shown in blue in Figure 3a).

A compaction band thickness of $\sim 1 \mathrm{~mm}$ is larger than seen in porous sandstones, where compaction bands are typically only 500-600 $\mu \mathrm{m}$ in thickness (two to four grainsthick; e.g., Tembe et al., 2008; Baud et al., 2012). Compaction band thicknesses of 1-3 mm have been observed in previous experimental studies on porous basalt (Adelinet et al., 2013), porous trachyandesite (Loaiza et al., 2012), porous andesite (Heap et al., 2015a, 2017), and porous dacite (Heap et al., 2016). The magnitude of stress dr sp seen in the mechanical data (Figure 4b), which are much larger than those seen in e: per nents on sandstone, are likely

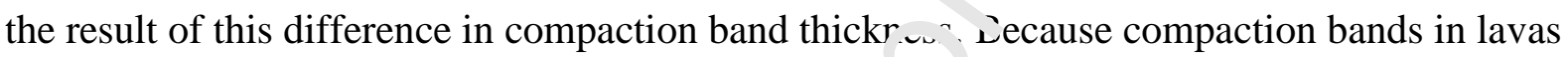
form as a result of cataclastic pore collapse, it follows wat the thickness of the compaction bands that form in these materials will be clos $\geqslant$ to ine pore diameter, the largest of which is > $1 \mathrm{~mm}$ in the studied lavas. We suggest ${ }^{\mathfrak{l}}$ at, because the compaction band in our andesite formed within the most porous part of the sample (Figure 5b), the zone that also likely contains the largest pores, the thi $n$ 'eso of compaction bands in lava will likely approach the diameter of the largest pore. F $x_{1}$ ariments on volcanic rocks that contain greatly different pore sizes and different pore -truudures (e.g., connectivity) are now required to explore this hypothesis.

The formation of compaction bands in sandstones requires a relatively homogeneous grain size distribution (e.g., Wang et al., 2008; Cheung et al., 2012). Within this narrow grain size distribution, compaction bands in sandstones have been characterised as either discrete or diffuse, where discrete bands propagate from one side of the sample to the other and diffuse bands are the result of the development of several small discrete bands (e.g., Baud et al., 2004). Sandstones that form discrete compaction bands are typically more microstructurally homogenous than those that form diffuse compaction bands (e.g., Louis et 
al., 2007). Our study, and previous studies (Loaiza et al., 2012; Adelinet et al., 2013; Heap et al., 2015a, 2016, 2017), has shown that, unlike sandstones, compaction bands can form in very microstructurally complex and heterogeneous lavas. Studies on compaction bands in volcanic rocks, including the present study, have also shown that these compaction bands do not appear to consist of several small discrete bands: they appear to propagate as a single entity from one side of the sample to the other, rather like a discrete compaction band (Figure 6c). However, although the compaction bands that form in lavas could be considered discrete, discrete compaction bands in sandstones are typically charactrise.' by a low tortuosity (e.g., Vajdova et al., 2003; Baud et al., 2004; Stanchits et al., 2 JU:'. By contrast, the tortuosity of the compaction band imaged here (Figure 6c), and that $\iota^{c}$ bands formed in previous studies (Loaiza et al., 2012; Adelinet et al., 2013; Heap et al., 2015a, 2016, 2017), is significantly higher. Because the compaction band image $1 . \cdot{ }^{\prime}$.is study formed in the zone of highest porosity (Figure $5 \mathrm{~b}$ ), the tortuosity of the band was therefore governed by the shape of porosity backbone from one side of this sample to the other within this zone (the band can only exist where there are pores) Si. - this porosity network is unlikely to be planar from one side of the sample to we oiher in such porous volcanic rocks (e.g., Figure 3a), compaction bands in pornus $\cdots$ canic rocks are very likely to present tortuous geometries, as observed here (Figure $v^{\prime}$ ) and in other studies (e.g., Heap et al., 2015a).

Compaction bands in sandstone can reduce sample permeability by $2-3$ orders of magnitude (e.g., Vajdova et al., 2004; Baud et al., 2012). The strain required to achieve this reduction in permeability depends on how much strain is required to form an efficient barrier, and more strain is required in sandstones that develop diffuse compaction bands compared to those that develop discrete compaction bands (e.g., Vajdova et al., 2004; Baud et al., 2012). Although compaction bands in lavas could be considered discrete, it is clear from our permeability measurements that they do not form an efficient barrier to fluid flow. 
Measurements showed that the permeability of sample LL3 was only reduced by a factor of $\sim 3$ following deformation to an axial strain of 0.03 . Heap et al. (2015a) showed that permeability of another andesite from Volcán de Colima was reduced by a factor of $\sim 3$ at an axial strain of 0.015 and by about one order of magnitude at an axial strain of 0.045 . Farquharson et al. (2017) also showed that axial strains $>0.015$ are required for permeability reductions of an order of magnitude in porous andesite. It is clear that, unlike in sandstones, compaction bands in porous lavas do not form an efficient barrier to fluid flow, a difference likely related to the complex nature of the well-connected pomsil; structure in these porous rocks (e.g., Figure 3a). Systematic laboratory experim $\mathrm{n}_{\mathrm{t}}$ are now required to further investigate compaction localisation in porous $v^{1}{ }^{1} a_{\text {a }}{ }^{i c}$ rocks and its influence on permeability.

\subsection{Volcanological implications}

A detailed understanding of stra $n$ localisation in volcanic rocks is required due to the influence of shear fractures and $\backsim \mathrm{m}_{\mathrm{r}} \backsim$ ction bands on permeability-a metric considered to influence volcanic character (c . ${ }^{\circ}$, Eichelberger et al., 1986; Mueller et al., 2008; Cassidy et al., 2018; Heap et al., 2019 ,--and on dome and flank stability, the collapse of which can generate pyroclastic un nsıy currents with potentially dire humanitarian and economic consequences (e.g., Cole et al., 1998; Komorowski et al., 2013). Our study shows that, unlike porous sandstones (e.g., Zhu and Wong, 1997), the permeability of high-porosity volcanic rocks increases following shear fracture formation at low effective pressure. An increase in the permeability of edifice-forming rocks could increase the efficiency of outgassing (e.g., Collinson and Neuberg, 2012), thus promoting effusive volcanic behaviour. Importantly, brittle deformation in porous lavas (at low effective pressure) may not be associated with decreases to permeability, as seen for sandstones of similar porosity (e.g., Zhu and Wong, 
1997). In the ductile regime (i.e. at a depth between 1 and $1.5 \mathrm{~km}$ ), compaction bands will form within high-porosity zones and result in the compaction of the well-connected, porosity backbone that supports high permeability. Therefore, although compaction bands in lavas form within a microstructurally complex and well-connected porosity backbone, a factor that may limit the extent to which they reduce permeability (compared to sandstones; Vajdova et al., 2004; Baud et al., 2012), they are associated with reductions to permeability (as seen in previous laboratory studies: Heap et al., 2015a; Farquharson et al., 2017). A decrease in the permeability of edifice-forming rocks could decrease the sfficisncy of outgassing (e.g., Collinson and Neuberg, 2012), thus promoting explosive w lcanic behaviour. Finally, we note that compaction bands in volcanic edifices will als , reate a permeability anisotropy, an important consideration in volcanic systems (e.g., Fa qu. arson and Wadsworth, 2018).

\section{Conclusions}

To better understand strain lu alisation in porous volcanic rocks, we performed porosity and DVC analyses on Y-r:? computed tomography images of porous andesite deformed in the brittle and duc ile regimes. These analyses reveal that strain localisation in a sample deformed in the brittı $r$ gime manifested as a $\sim 1 \mathrm{~mm}$-wide, dilatational shear fracture orientated at an angle $\mathrm{c}^{\mathrm{c}} 4 \mathrm{U}-45^{\circ}$ to the maximum principal stress. For a sample deformed in the ductile regime, strain localised into $\sim 1 \mathrm{~mm}$-thick, undulating compaction bands orientated sub-perpendicular to the maximum principal stress with little evidence of shear. These compaction bands likely formed following stress drops seen in the mechanical data and formed within the zones of highest porosity, within the large, well-connected porosity backbone of the sample. Shear fracturing in the brittle regime and the formation of compaction bands in the ductile regime were seen to result in an increase and decrease in sample permeability, respectively. Our study also highlights that X-ray tomography 
combined with DVC can provide insight into deformation and strain localisation in porous volcanic rocks, the importance of which is emphasised by their influence on, for example, permeability and therefore outgassing and eruption style (effusive or explosive). DVC on a wide range of volcanic rocks (characterised by different pore sizes and shapes and pore structures), coupled with laboratory measurements of permeability, offers an exciting avenue for future research.

\section{Acknowledgements}

We thank Thierry Reuschlé and Erika Tudisco. N`ck Varley and Jamie Farquharson are thanked for their help in collecting the andesite $b^{1} n_{\mathrm{n}}$ This study was funded by LabEx Grant ANR-11-LABX-0050_G-EAU-THERMIE-FRL FONDE (this research therefore benefited from state funding managed by the $/ g_{2} n \_$National de la Recherche (ANR) as part of the "Investissements d'avenir" progra $\urcorner$ ) Funding for this project was also provided by the Research Council of Norway: grant 2/2?.17 (ARGUS) to François Renard and grant 300435 to Jess McBeck. Lucille Carbille ac awledges funding from the Doctoral School at the University of Strasbourg. X-ra, images can be made available on request. The comments of two anonymous reviewers $h \epsilon_{i} \sim d$ improve this manuscript. 


\section{Figure captions}

Figure 1. (a) Image from GoogleEarth $\odot$ showing Volcán de Colima (height $=3820 \mathrm{~m}$ ), Mexico. The block of andesite used for this study was collected in the "La Lumbre" debris flow track and is indicated by the white arrow. Inset shows a map of Mexico showing the location of Volcán de Colima (the red triangle). (b) Backscattered scanning electron microscope image of the studied andesite. The porosity is shown in black.

Figure 2. Histogram of the grey-scale values of the X-ra to nography data for sample LL3. The grey-scale indicates the relative X-ray attenuation ce afficient, where 0 is black (lowest attenuation) and 255 is white (highest attenuation) $\mathrm{I} \cdot \mathrm{se}_{\llcorner}$. $2 \mathrm{D}$ vertical slice extracted from the 3D X-ray tomography image of the undeform $: a \cdot \mathbf{I} 3$ andesite sample (cubic voxels of width $23 \mu \mathrm{m})$.

Figure 3. Porosity structure. (a) ${ }^{2} \mathrm{i}_{1}$.age of an undeformed andesite sample (LL3), created using the X-ray image slices $\left(\left\llcorner^{2} \mathrm{um} / \mathrm{voxel}\right)\right.$, showing the porosity structure. Each connected pore is shown in a differ.. cuiour. (b) The same 3D image shown in panel (a), but with the large, connected pore (c' 'oured dark blue in panel (a)) removed. (c) Histogram showing the distribution of pore radii for the unconnected pores shown in panel (b).

Figure 4. Mechanical data. (a) Stress-strain curve for the sample (LL5) deformed at an effective pressure of $10 \mathrm{MPa}$ (in the brittle regime). (b) Stress-strain curve for the sample (LL3) deformed at an effective pressure of $50 \mathrm{MPa}$ (in the ductile regime). (c) Porosity reduction as a function of axial strain for the sample (LL5) deformed at an effective pressure of $10 \mathrm{MPa}$ (in the brittle regime). (d) Porosity reduction as a function of axial strain for the 
sample (LL3) deformed at an effective pressure of $50 \mathrm{MPa}$ (in the ductile regime). The positions of the X-ray scans are indicated on the stress-strain curves.

Figure 5. Porosity profiles. (a) Porosity as a function of sample length (sample LL5) before and after deformation at an effective pressure of $10 \mathrm{MPa}$ (in the brittle regime). (b) Porosity as a function of sample length (sample LL3) before and after one and two rounds of deformation (see Figure $4 \mathrm{~b}$ ) at an effective pressure of $50 \mathrm{MPa}$ (in the ductile regime).

Figure 6. Digital volume correlation data. (a) Diverger ce 'volumetric strain) and curl (a proxy for shear strain) of the displacement field f $\wedge$ ' se sample (LL5) deformed at an effective pressure of $10 \mathrm{MPa}$ (in the brittle regime) ( $\mathrm{c}$; Divergence (volumetric strain) and

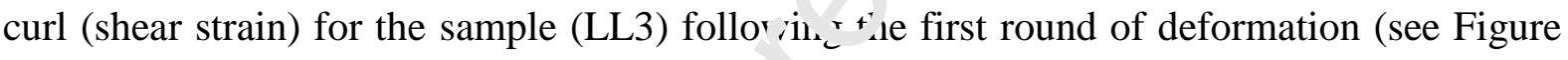
4c) at an effective pressure of $50 \mathrm{MPa}$ in the ductile regime). (b) Divergence (volumetric strain) and curl (shear strain) for the sai nle (LL3) following the second round of deformation (see Figure 4c) at an effective pre $\backsim$ in of $50 \mathrm{MPa}$ (in the ductile regime).

Figure 7. 2D vertical slices $t^{\text {th }}$ acted from the 3D tomography data volume of the intact LL3 sample and the same sa. npı following the first round of deformation at an effective pressure of $50 \mathrm{MPa}$ (in the ductile regime). This image shows the compaction band at the top of the sample that was missed by the porosity and DVC analyses. The lower image shows a zoomed image in which collapsed pores are highlighted by white arrows. 


\section{References}

Adelinet, M., Fortin, J., Schubnel, A., \& Guéguen, Y. (2013). Deformation modes in an Icelandic basalt: from brittle failure to localized deformation bands. Journal of Volcanology and Geothermal Research, 255, 15-25.

Anderson, S. W., \& Fink, J. H. (1990). The development and distribution of surface textures at the Mount St. Helens dome. In Lava flows and domes (pp. 25-46). Springer, Berlin, Heidelberg.

Baker, D. R., Polacci, M., \& LaRue, A. (2011). A study on the reproducibility of counting vesicles in volcanic rocks. Geosphere, 7(1), 70-78.

Baud, P., Klein, E., \& Wong, T.-f. (2004). Compaction localization in poruu sandstones: spatial evolution of damage and acoustic emission activity. Journal of Structural Geolc 'vv ` 6(4), 603-624.

Baud, P., Meredith, P., \& Townend, E. (2012). Permeability e ro tir.. during triaxial compaction of an anisotropic porous sandstone. Journal of Geophysical Re iear. h: Solid Earth, 117(B5).

Baud, P., Reuschlé, T., Ji, Y., Cheung, C. S., \& Wong, T.-f. (2015). Mechanical compaction and strain localization in Bleurswiller sandstone. Journal oj Gr sphysical Research: Solid Earth, 120(9), 65016522.

Bauer, D., Youssef, S., Fleury, M., Bekri, S Rosenbıig, E., \& Vizika, O. (2012). Improving the estimations of petrophysical transport behavior of ar , nate rocks using a dual pore network approach combined with computed microtomography. $\operatorname{Tr}$ nspe ${ }^{2 t}$ in porous media, 94(2), 505-524.

Benson, P. M., Thompson, B. D., Me ' dith, P. G., Vinciguerra, S., \& Young, R. P. (2007). Imaging slow failure in triaxially deformed L. na basalt using 3D acoustic-emission location and X-ray computed tomography. Geopr. sic. 1 r.esearch Letters, 34(3).

Benson, P. M., Heap, M. J., Lavallée, Y., Flaws, A., Hess, K. U., Selvadurai, A. P. S., ... \& Schillinger, B. (2012). Laboratory simulations of tensile fracture development in a volcanic conduit via cyclic magma pressurisation. Earth and Planetary Science Letters, 349, 231-239.

Bésuelle, P. (2001). Evolution of strain localisation with stress in a sandstone: brittle and semi-brittle regimes. Physics and Chemistry of the Earth, Part A: Solid Earth and Geodesy, 26(1-2), 101-106.

Bésuelle, P., Baud, P., \& Wong, T.-f. (2003). Failure mode and spatial distribution of damage in Rothbach sandstone in the brittle-ductile transition. In Thermo-Hydro-Mechanical Coupling in Fractured Rock (pp. 851-868). Birkhäuser, Basel. 
Black, B. A., Manga, M., \& Andrews, B. (2016). Ash production and dispersal from sustained low-intensity Mono-Inyo eruptions. Bulletin of Volcanology, 78(8), 57.

Brace, W. F., Paulding Jr, B. W., \& Scholz, C. H. (1966). Dilatancy in the fracture of crystalline rocks. Journal of Geophysical Research, 71(16), 3939-3953.

Bubeck, A., Walker, R. J., Healy, D., Dobbs, M., \& Holwell, D. A. (2017). Pore geometry as a control on rock strength. Earth and Planetary Science Letters, 457, 38-48.

Bubeck, A., Walker, R. J., Imber, J., \& MacLeod, C. J. (2018). Normal fault growth in layered basaltic rocks: The role of strain rate in fault evolution. Journal of Structural Geology, 115, 103-120.

Bull, K. F., Anderson, S. W., Diefenbach, A. K., Wessels, R. L., \& Henton S. M. (2013). Emplacement of the final lava dome of the 2009 eruption of Redoubt Volcano, 4lasi a. Journal of Volcanology and Geothermal Research, 259, 334-348.

Caine, J. S., Evans, J. P., \& Forster, C. B. (1996) : 'u. zone architecture and permeability structure. Geology, 24(11), 1025-1028.

Cashman, K. V., Thornber, C. R., \& Pallister, J. S. (2( ९), . Trom dome to dust: Shallow crystallization and fragmentation of conduit magma duri $g$ he :2004-2006 dome extrusion of Mount St. Helens, Washington (No. 1750-19, pp. 387-413). US ¿`ological Survey.

Cassidy, M., Manga, M., Cashman, K., \&. Bac:mann, O. (2018). Controls on explosive-effusive volcanic eruption styles. Nature Communi_u. imı, 9(1), 1-16.

Castro, J. M., Dingwell, D. B., Nich` s, A. R., \& Gardner, J. E. (2005). New insights on the origin of flow bands in obsidian. Special Pape, - G' ological Society of America, 396, 55.

Castro, J. M., Bindeman, ' N. Tut en, H., \& Schipper, C. I. (2014). Explosive origin of silicic lava: textural and SD-H2O evidence for pyroclastic degassing during rhyolite effusion. Earth and Planetary Science Letters, 405, 52-61.

Cavailhes, T., \& Rotevatn, A. (2018). Deformation bands in volcaniclastic rocks-Insights from the Shihtiping tuffs, Coastal Range of Taiwan. Journal of Structural Geology, 113, 155-175.

Charalampidou, E. M., Hall, S. A., Stanchits, S., Viggiani, G., \& Lewis, H. (2010). Characterization of Shear and Compaction Bands in Sandstone Using X-Ray Tomography and 3D Digital Image Correlation. Advances in Computed Tomography for Geomaterials: GeoX 2010, 59-66. 
Charalampidou, E. M., Hall, S. A., Stanchits, S., Lewis, H., \& Viggiani, G. (2011). Characterization of shear and compaction bands in a porous sandstone deformed under triaxial compression. Tectonophysics, 503(1-2), 8-17.

Cilona, A., Faulkner, D. R., Tondi, E., Agosta, F., Mancini, L., Rustichelli, A., ... \& Vinciguerra, S. (2014). The effects of rock heterogeneity on compaction localization in porous carbonates. Journal of Structural Geology, 67, 75-93.

Coats, R., Kendrick, J. E., Wallace, P. A., Miwa, T., Hornby, A. J., Ashworth, J. D., ... \& Lavallée, Y. (2018). Failure criteria for porous dome rocks and lavas: a study of Mt. Unzen, Japan. Solid Earth, 9(6), 12991328.

Cole, P. D., Calder, E. S., Druitt, T. H., Hoblitt, R., Robertson, R., Spi rks, .. S. J., \& Young, S. R. (1998). Pyroclastic flows generated by gravitational instability of th ? 19 6-97 lava dome of Soufriere Hills Volcano, Montserrat. Geophysical Research Letters, 25(1 $\sim, 3,34.25428$.

Collinson, A. S. D., \& Neuberg, J. W. (2012). Gas storage. tra sport and pressure changes in an evolving permeable volcanic edifice. Journal of Volcanolog.' na Geothermal Research, 243, 1-13.

Darmawan, H., Walter, T. R., Brotopuspito, K. S , \& Vani ika, I. G. M. A. (2018). Morphological and structural changes at the Merapi lava dome monitored 11 ? $012-15$ using unmanned aerial vehicles (UAVs). Journal of Volcanology and Geothermal Resf _. $\cdot h, .249,256-267$.

Dautriat, J., Bornert, M., Gland, N., D «1. nov, A., \& Raphanel, J. (2011). Localized deformation induced by heterogeneities in poi' 'Is carbonate analysed by multi-scale digital image correlation. Tectonophysic-50r(1-2), 100-116.

Degruyter, W., Burgisse: A. Bar amann, O., \& Malaspinas, O. (2010). Synchrotron X-ray microtomography and lattice Boltzmann s mulations of gas flow through volcanic pumices. Geosphere, 6(5), 470-481.

Eggertsson, G. H., Lavallée, Y., Kendrick, J. E., \& Markússon, S. H. (2018). Improving fluid flow in geothermal reservoirs by thermal and mechanical stimulation: The case of Krafla volcano, Iceland. Journal of Volcanology and Geothermal Research.

Eichelberger, J. C., Carrigan, C. R., Westrich, H. R., \& Price, R. H. (1986). Non-explosive silicic volcanism. Nature, 323(6089), 598-602.

Farquharson, J. I., Heap, M. J., Lavallée, Y., Varley, N. R., \& Baud, P. (2016a). Evidence for the development of permeability anisotropy in lava domes and volcanic conduits. Journal of Volcanology and Geothermal Research, 323, 163-185. 
Farquharson, J. I., Heap, M. J., \& Baud, P. (2016b). Strain-induced permeability increase in volcanic rock. Geophysical Research Letters, 43(22), 11-603.

Farquharson, J. I., Baud, P., \& Heap, M. J. (2017). Inelastic compaction and permeability evolution in volcanic rock. Solid Earth, 8(2), 561.

Farquharson, J. I., \& Wadsworth, F. B. (2018). Upscaling permeability in anisotropic volcanic systems. Journal of Volcanology and Geothermal Research, 364, 35-47.

Fortin, J., Stanchits, S., Dresen, G., \& Guéguen, Y. (2006). Acoustic emission and velocities associated with the formation of compaction bands in sandstone. Journal of Geophysical Research: Solid Earth, 111(B10).

Fortin, J., Stanchits, S., Vinciguerra, S., \& Guéguen, Y. (2011). Influenc of t ermal and mechanical cracks on permeability and elastic wave velocities in a basalt from Mt. itna volcano subjected to elevated pressure. Tectonophysics, 503(1-2), 60-74.

Fusseis, F., Schrank, C., Liu, J., Karrech, A., Llana-Funez, S, X. ^o, X., \& Regenauer-Lieb, K. (2012). Pore formation during dehydration of polycrystalline syp um observed and quantified in a time-series synchrotron radiation based X-ray micro-t tmo ,rapı.y experiment. Solid Earth, 3(1), 71-86.

Gardner, J. E., Wadsworth, F. B., Llewellin, E. W., Watkins, J. M., \& Coumans, J. P. (2018). Experimental

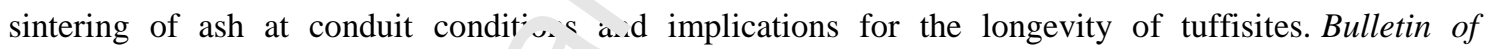
Volcanology, 80(3), 23.

Giachetti, T., Burgisser, A., Arbareı, I.., Lruitt, T. H., \& Kelfoun, K. (2011). Quantitative textural analysis of Vulcanian pyroclasts (Mo. ${ }^{+}$serr at) using multi-scale X-ray computed microtomography: comparison with results from 2D ir age 'nal sis. Bulletin of Volcanology, 73(9), 1295-1309.

Glicken, H. (1996). Rockslite. lebris avalanche of May 18, 1980, Mount St. Helens volcano, Washington (No. 96-677). US Geological Survey.

Gonnermann, H. M., \& Manga, M. (2005). Flow banding in obsidian: A record of evolving textural heterogeneity during magma deformation. Earth and Planetary Science Letters, 236(1-2), 135-147.

Gudmundsson, A. (2011). Rock fractures in geological processes. Cambridge University Press.

Hale, A. J., \& Wadge, G. (2008). The transition from endogenous to exogenous growth of lava domes with the development of shear bands. Journal of Volcanology and Geothermal Research, 171(3-4), 237-257. 
Heap, M. J., Lavallée, Y., Petrakova, L., Baud, P., Reuschlé, T., Varley, N. R., \& Dingwell, D. B. (2014). Microstructural controls on the physical and mechanical properties of edifice-forming andesites at Volcán de Colima, Mexico. Journal of Geophysical Research: Solid Earth, 119(4), 2925-2963.

Heap, M. J., Farquharson, J. I., Baud, P., Lavallée, Y., \& Reuschlé, T. (2015a). Fracture and compaction of andesite in a volcanic edifice. Bulletin of Volcanology, 77(6), 55.

Heap, M. J., Brantut, N., Baud, P., \& Meredith, P. G. (2015b). Time-dependent compaction band formation in sandstone. Journal of Geophysical Research: Solid Earth, 120(7), 4808-4830.

Heap, M. J., \& Wadsworth, F. B. (2016). Closing an open system: pore pressure changes in permeable edifice rock at high strain rates. Journal of Volcanology and Geothermal Res. rrch, 315, 40-50.

Heap, M. J., \& Kennedy, B. M. (2016). Exploring the scale-dependent pc "mea sility of fractured andesite. Earth and Planetary Science Letters, 447, 139-150.

Heap, M. J., Russell, J. K., \& Kennedy, L. A. (2016). Mechan -ai henaviour of dacite from Mount St. Helens (USA): A link between porosity and lava dome extrası mechanism (dome or spine)? Journal of Volcanology and Geothermal Research, 328, 159- 7\%.

Heap, M. J., Violay, M., Wadsworth, F. B., \& ' as: zur, ․ (2017). From rock to magma and back again: the evolution of temperature and deformation n shanism in conduit margin zones. Earth and Planetary Science Letters, 463, 92-100.

Heap, M. J., Coats, R., Chen, C. F., Vı.ı.' 1v., Lavallée, Y., Kendrick, J., ... \& Reuschlé, T. (2018). Thermal resilience of microcracked an 'sitic dome rocks. Journal of Volcanology and Geothermal Research, 367, 20-30.

Heap, M. J., Tuffen, H. W dsw srth, F. B., Reuschlé, T., Castro, J. M., \& Schipper, C. I. (2019a). The permeability evolutior of tuffisites and implications for outgassing through dense rhyolitic magma. Journal of Geophysical Research: Solid Earth, 124(8), 8281-8299.

Heap, M. J., Troll, V. R., Kushnir, A. R., Gilg, H. A., Collinson, A. S., Deegan, F. M., ... \& Walter, T. R. (2019b). Hydrothermal alteration of andesitic lava domes can lead to explosive volcanic behaviour. Nature Communications, 10(1), 1-10.

Hill, R.E. (1989). Analysis of Deformation Bands in the Aztec Sandstone. Valley of Fire State Park, Nevada. Master Thesis, Univ. Nevada, Las Vegas.

Holland, M., Urai, J. L., \& Martel, S. (2006). The internal structure of fault zones in basaltic sequences. Earth and Planetary Science Letters, 248(1-2), 301-315. 
Hornby, A. J., Kendrick, J. E., Lamb, O. D., Hirose, T., De Angelis, S., von Aulock, F. W., ... \& Hess, K. U. (2015). Spine growth and seismogenic faulting at Mt. Unzen, Japan. Journal of Geophysical Research: Solid Earth, 120(6), 4034-4054.

Huang, L., Baud, P., Cordonnier, B., Renard, F., Liu, L., \& Wong, T.-f. (2019). Synchrotron X-ray imaging in 4D: Multiscale failure and compaction localization in triaxially compressed porous limestone. Earth and Planetary Science Letters, 528, 115831.

Iverson, R. M., Dzurisin, D., Gardner, C. A., Gerlach, T. M., LaHusen, R. G., Lisowski, M., ... \& Pallister, J. S. (2006). Dynamics of seismogenic volcanic extrusion at Mount St Helens in 2004-05. Nature, 444(7118), 439-443.

Jamtveit, B., Kobchenko, M., Austrheim, H., Malthe-Sørenssen, A., Røy. e, A , \& Svensen, H. (2011). Porosity evolution and crystallization-driven fragmentation during weat 'erin; of andesite. Journal of Geophysical Research: Solid Earth, 116(B12).

Jamtveit, B., Krotkiewski, M., Kobchenko, M., Renard, F., \& f.ng. sluta, L. (2014). Pore-space distribution and transport properties of an andesitic intrusion. Eart. r nd Planetary Science Letters, 400, 123-129.

Ji, Y., Baud, P., Vajdova, V., \& Wong, T.-f. (20 2). Chaı..cterization of pore geometry of Indiana limestone in relation to mechanical compaction. Oil \& Gas Science and Technology-Revue d'IFP Energies Nouvelles, 67(5), 753-775.

Ji, Y., Hall, S. A., Baud, P., \& Wong, '..-- ( $\angle$ v15). Characterization of pore structure and strain localization in Majella limestone by X-ray - smpuced tomography and digital image correlation. Geophysical Journal International, 200(2), 701 719 .

Kandula, N., Cordonnier, R., ?oll $\Leftarrow$, E., Weiss, J., Dysthe, D. K., \& Renard, F. (2019). Dynamics of microscale precursors during brittl- compressive failure in Carrara marble. Journal of Geophysical Research: Solid Earth, 124(6), 6121-6139.

Kendrick, J. E., Lavallée, Y., Hess, K. U., Heap, M. J., Gaunt, H. E., Meredith, P. G., \& Dingwell, D. B. (2013). Tracking the permeable porous network during strain-dependent magmatic flow. Journal of Volcanology and Geothermal Research, 260, 117-126.

Kennedy, L. A., \& Russell, J. K. (2012). Cataclastic production of volcanic ash at Mount Saint Helens. Physics and Chemistry of the Earth, Parts A/B/C, 45, 40-49.

Komorowski, J. C., Jenkins, S., Baxter, P. J., Picquout, A., Lavigne, F., Charbonnier, S., ... \& Budi-Santoso, A. (2013). Paroxysmal dome explosion during the Merapi 2010 eruption: Processes and facies relationships 
of associated high-energy pyroclastic density currents. Journal of Volcanology and Geothermal Research, 261, 260-294.

Lagmay, A. M. F., De Vries, B. V. W., Kerle, N., \& Pyle, D. M. (2000). Volcano instability induced by strikeslip faulting. Bulletin of Volcanology, 62(4-5), 331-346.

Lamb, O. D., De Angelis, S., Umakoshi, K., Hornby, A. J., Kendrick, J. E., \& Lavallée, Y. (2015). Repetitive fracturing during spine extrusion at Unzen volcano, Japan. Solid Earth, 6(4), 1277-1293.

Lavallée, Y., Benson, P. M., Heap, M. J., Hess, K. U., Flaws, A., Schillinger, B., ... \& Dingwell, D. B. (2013). Reconstructing magma failure and the degassing network of dome-building eruptions. Geology, 41(4), 515-518.

Lindquist, W. B., Venkatarangan, A., Dunsmuir, J., \& Wong, T.-f. (20 10). J ore and throat size distributions measured from synchrotron X-ray tomographic images if Fr ntainebleau sandstones. Journal of Geophysical Research: Solid Earth, 105(B9), 21509-215\%-.

Loaiza, S., Fortin, J., Schubnel, A., Guéguen, Y., Vinciguerra S., Pr. Moreira, M. (2012). Mechanical behavior and localized failure modes in a porous basalt fron t'e zores. Geophysical Research Letters, 39(19).

Lockner, D. (1993). The role of acoustic emissir $₫$ in the tudy of rock fracture. International Journal of Rock Mechanics and Mining Sciences \& Geomechu, ics Abstracts, 30, No. 7, 883-899.

Louis, L., Wong, T.-f., Baud, P., \& Te...e, ‥ (2006). Imaging strain localization by X-ray computed tomography: discrete compactio'. w. nas in Diemelstadt sandstone. Journal of Structural Geology, 28(5), 762-775.

Louis, L., Wong, T.-f., \& Baud, ? (2 N7). Imaging strain localization by X-ray radiography and digital image correlation: Defor 'ati $\eta$ ba ıds in Rothbach sandstone. Journal of Structural Geology, 29(1), 129-140.

McBeck, J., Kobchenko, M. Hall, S. A., Tudisco, E., Cordonnier, B., Meakin, P., \& Renard, F. (2018). Investigating the onset of strain localization within anisotropic shale using digital volume correlation of time-resolved X-ray microtomography images. Journal of Geophysical Research: Solid Earth, 123(9), 7509-7528.

McBeck, J. A., Cordonnier, B., Vinciguerra, S., \& Renard, F. (2019). Volumetric and shear strain localization in Mt. Etna basalt. Geophysical Research Letters, 46(5), 2425-2433.

McBeck, J., Ben-Zion, Y., \& Renard, F. (2020). The mixology of precursory strain partitioning approaching brittle failure in rocks. Geophysical Journal International, 221(3), 1856-1872. 
Mitchell, T. M., \& Faulkner, D. R. (2008). Experimental measurements of permeability evolution during triaxial compression of initially intact crystalline rocks and implications for fluid flow in fault zones. Journal of Geophysical Research: Solid Earth, 113(B11).

Mollema, P. N., \& Antonellini, M. A. (1996). Compaction bands: a structural analog for anti-mode I cracks in aeolian sandstone. Tectonophysics, 267(1-4), 209-228.

Mueller, S., Scheu, B., Spieler, O., \& Dingwell, D. B. (2008). Permeability control on magma fragmentation. Geology, 36(5), 399-402.

Moran, P. A. (1948). The interpretation of statistical maps. Journal of the Royal Statistical Society. Series B (Methodological), 10(2), 243-251.

Nara, Y., Meredith, P. G., Yoneda, T., \& Kaneko, K. (2011). Influence f ma ro-fractures and micro-fractures on permeability and elastic wave velocities in basalt at elevat d pr ssure. Tectonophysics, 503(1-2), 5259.

Okubo, C. H. (2014). Brittle deformation and slope failure at the Vorth Menan butte tuff cone, eastern Snake River plain, Idaho. Journal of Volcanology and Gt to ıer nal Research, 278, 86-95.

Pardo, N., Cronin, S. J., Wright, H. M., Schipr _r, J. 1., Smith, I., \& Stewart, B. (2014). Pyroclast textural variation as an indicator of eruption con $m$ steadiness in andesitic Plinian eruptions at Mt. Ruapehu. Bulletin of Volcanology, 7f:ㄱ, $0: 2$.

Polacci, M., Baker, D. R., Mancini, L. Iomua, G., \& Zanini, F. (2006). Three-dimensional investigation of volcanic textures by X-ray nicrocomography and implications for conduit processes. Geophysical Research Letters, 33(13).

Renard, F., Cordonnier, B., Ko schenko, M., Kandula, N., Weiss, J., \& Zhu, W. (2017). Microscale characterization of rur ure nucleation unravels precursors to faulting in rocks. Earth and Planetary Science Letters, 476, 69-78.

Renard, F., McBeck, J., Cordonnier, B., Zheng, X., Kandula, N., Sanchez, J. R., ... \& Fusseis, F. (2019). Dynamic in situ three-dimensional imaging and digital volume correlation analysis to quantify strain localization and fracture coalescence in sandstone. Pure and Applied Geophysics, 176(3), 1083-1115.

Rotevatn, A., Thorsheim, E., Bastesen, E., Fossmark, H. S., Torabi, A., \& Sælen, G. (2016). Sequential growth of deformation bands in carbonate grainstones in the hangingwall of an active growth fault: Implications for deformation mechanisms in different tectonic regimes. Journal of Structural Geology, 90, 27-47. 
Rust, A. C., Manga, M., \& Cashman, K. V. (2003). Determining flow type, shear rate and shear stress in magmas from bubble shapes and orientations. Journal of Volcanology and Geothermal Research, 122(12), 111-132.

Rust, A. C., Cashman, K. V., \& Wallace, P. J. (2004). Magma degassing buffered by vapor flow through brecciated conduit margins. Geology, 32(4), 349-352.

Rutter, E. H. (1986). On the nomenclature of mode of failure transitions in rocks. Tectonophysics, 122(3-4), 381-387.

Ryan, A. G., Friedlander, E. A., Russell, J. K., Heap, M. J., \& Kennedy, L. A. (2018). Hot pressing in conduit faults during lava dome extrusion: Insights from Mount St. Helen, 2004-2008. Earth and Planetary Science Letters, 482, 171-180.

Ryan, A. G., Heap, M. J., Russell, J. K., Kennedy, L. A., \& M. Clynı ? (2( 20). Cyclic shear zone cataclasis and sintering during lava dome extrusion: Insights frr... Liaos Crags, Lassen Volcanic Center (USA). Journal of Volcanology and Geothermal Researr h. . cepted.

Saubin, E., Tuffen, H., Gurioli, L., Owen, J., Castro, J. M Jer o, K., ... \& Wehbe, K. (2016). Conduit dynamics in transitional rhyolitic activity record $\lrcorner \mathrm{L} /$ th.'fisite vein textures from the 2008-2009 Chaitén Eruption. Frontiers in Earth Science, 4, 59.

Schipper, C. I., Mandon, C., Maksimenko, ^.., Ca ‘ro, J. M., Conway, C. E., Hauer, P., ... \& Kilgour, G. (2017). Vapor-phase cristobalite as a dracie indicator of magmatic pore structure and halogen degassing: an example from White Island ve cano (New Zealand). Bulletin of Volcanology, 79(10), 74.

Scholz, C. H. (1968). Microfı - turi ig and the inelastic deformation of rock in compression. Journal of Geophysical Rese. ${ }^{r c h}, 73(<), 1417-1432$.

Shea, T., Houghton, B. F., Gur oli, L., Cashman, K. V., Hammer, J. E., \& Hobden, B. J. (2010). Textural studies of vesicles in volcanic rocks: an integrated methodology. Journal of Volcanology and Geothermal Research, 190(3-4), 271-289.

Shahin, G., Papazoglou, A., Marinelli, F., \& Buscarnera, G. (2019). Simulation of localized compaction in Tuffeau de Maastricht based on evidence from X-ray tomography. International Journal of Rock Mechanics and Mining Sciences, 121, 104039.

Song, S. R., Jones, K. W., Lindquist, B. W., Dowd, B. A., \& Sahagian, D. L. (2001). Synchrotron X-ray computed microtomography: studies on vesiculated basaltic rocks. Bulletin of Volcanology, 63(4), 252263. 
Thompson, E. S., Saveyn, P., Declercq, M., Meert, J., Guida, V., Eads, C. D., Robles, E. S. J., \& Britton, M. M. (2018). Characterisation of heterogeneity and spatial autocorrelation in phase separating mixtures using Moran’s I. Journal of Colloid and Interface Science, 513, 180-187.

Townend, E., Thompson, B. D., Benson, P. M., Meredith, P. G., Baud, P., \& Young, R. P. (2008). Imaging compaction band propagation in Diemelstadt sandstone using acoustic emission locations. Geophysical Research Letters, 35(15).

Tudisco, E., Hall, S. A., Charalampidou, E. M., Kardjilov, N., Hilger, A., \& Sone, H. (2015). Full-field measurements of strain localisation in sandstone by neutron tomography and 3D-volumetric digital image correlation. Physics Procedia, 69(509-515).

Tudisco, E., Andò, E., Cailletaud, R., \& Hall, S. A. (2017). TomoWa1 22: a local digital volume correlation code. SoftwareX, 6, 267-270.

Tuffen, H., Dingwell, D. B., \& Pinkerton, H. (2003). Repeated ... th.e and healing of silicic magma generate flow banding and earthquakes? Geology, 31(12), 1089-179.

Varley, N., Connor, C. B., \& Komorowski, J. C. (Eds.). ('0) э). Volcán de Colima: Portrait of a Persistently Hazardous Volcano. Springer.

Voight, B. (2000). Structural stability of andesite vu anoes and lava domes. Philosophical Transactions of the Royal Society of London. Series A: N.ther. atical, Physical and Engineering Sciences, 358(1770), 16631703.

Voltolini, M., Zandomeneghi, D., M. רcinı, L., \& Polacci, M. (2011). Texture analysis of volcanic rock samples: quantitative study of cry ${ }^{\text {tals }}$ ind vesicles shape preferred orientation from X-ray microtomography data. Journal of $V \cdot{ }^{\prime} \mathrm{Ca}$, slog, and Geothermal Research, 202(1-2), 83-95.

Wadsworth, F. B., Vasseur I, Llewellin, E. W., Dobson, K. J., Colombier, M., Von Aulock, F. W., ... \& Lavallée, Y. (2017). Topological inversions in coalescing granular media control fluid-flow regimes. Physical Review E, 96(3), 033113.

Wadsworth, F. B., Vasseur, J., Schauroth, J., Llewellin, E. W., Dobson, K. J., Havard, T., ... \& Hess, K. U. (2019). A general model for welding of ash particles in volcanic systems validated using in situ X-ray tomography. Earth and Planetary Science Letters, 525, 115726.

Walker, R. J., Holdsworth, R. E., Armitage, P. J., \& Faulkner, D. R. (2013). Fault zone permeability structure evolution in basalts. Geology, 41(1), 59-62. 
Walker, R. J., Holdsworth, R. E., Imber, J., Faulkner, D. R., \& Armitage, P. J. (2013). Fault zone architecture and fluid flow in interlayered basaltic volcaniclastic-crystalline sequences. Journal of Structural Geology, 51, 92-104.

Walter, T. R., Subandriyo, J., Kirbani, S., Bathke, H., Suryanto, W., Aisyah, N., ... \& Dahm, T. (2015). Volcano-tectonic control of Merapi's lava dome splitting: The November 2013 fracture observed from high resolution TerraSAR-X data. Tectonophysics, 639, 23-33.

Wang, B., Chen, Y., \& Wong, T.-f. (2008). A discrete element model for the development of compaction localization in granular rock. Journal of Geophysical Research: Solid Earth, 113(B3).

Watts, R. B., Herd, R. A., Sparks, R. S. J., \& Young, S. R. (2002). Grow patterns and emplacement of the andesitic lava dome at Soufriere Hills Volcano, Montserrat. Geolo 'ical Jociety, London, Memoirs, 21(1), 115-152.

Wilson, J. E., Goodwin, L. B., \& Lewis, C. J. (2003). Г_rn.tion bands in nonwelded ignimbrites: Petrophysical controls on fault-zone deformation and evidence of preferential fluid flow. Geology, 31(10), 837-840.

Zandomeneghi, D., Voltolini, M., Mancini, L. Bı n, 1, Dreossi, D., \& Polacci, M. (2010). Quantitative analysis of X-ray microtomography, nages of geomaterials: Application to volcanic rocks. Geosphere, 6(6), 793-804.

Zhang, T., \& Lin, G. (2016). On Morə _. I uvefficient under heterogeneity. Computational Statistics \& Data Analysis, 95, 83-94.

Zhu, W., Baud, P., Vinciguerra, S., d: Wong, T.-f. (2011). Micromechanics of brittle faulting and cataclastic flow in Alban Hil' tui Jor rnal of Geophysical Research: Solid Earth, 116(B6).

Zhu, W., Baud, P., Vinciguer' , S., \& Wong, T. F. (2016). Micromechanics of brittle faulting and cataclastic flow in Mount Etna basalt. Journal of Geophysical Research: Solid Earth, 121(6), 4268-4289.

Zhu, W., \& Wong, T.-f. (1997). The transition from brittle faulting to cataclastic flow: Permeability evolution. Journal of Geophysical Research: Solid Earth, 102(B2), 3027-3041. 
Imaging strain localisation in porous andesite using digital volume correlation

Michael J. Heap, Patrick Baud, Jessica A. McBeck, François Renard, Lucille Carbillet, and Stephan A. Hall

\section{Author statement}

Michael J. Heap: Conceptualisation, Investigation, Writ ng - Original Draft, Visualisation, Project Administration. Patrick Baud: Conceptualisatic 1, lıvestigation, Writing - Review \& Editing, Project Administration. Jessica A. McBeck. I rnıal analysis, Writing - Review \& Editing, Visualisation. François Renard: Formal a al; sis, Writing - Review \& Editing, Visualisation. Lucille Carbillet: Formal analysis. Vritı。g - Review \& Editing. Stephan A. Hall: Formal analysis, Investigation, Writing - ?e $\mathrm{j}$ i $\cdot \mathrm{w} \&$ Editing. 


\section{Declaration of interests}

$\bigotimes$ The authors declare that they have no known competing financial interests or personal relationships that could have appeared to influence the work reported in this paper.

$\square$ The authors declare the following financial interests/personal relationships which may be considered as potential competing interests: 
Imaging strain localisation in porous andesite using digital volume correlation

Michael J. Heap, Patrick Baud, Jessica A. McBeck, François Renard, Lucille Carbillet, and Stephan A. Hall

\section{Highlights}

- Shear fractures associated with localised dilation and w ${ }^{-r}$,eability increase.

- Compaction bands associated with localised con. 'action and permeability decrease.

- Compaction bands form in the most porous nart of the sample, within the wellconnected porosity backbone.

- Geometric characteristics of com Jac on vands in lavas likely related to pore size and structure.

- Digital volume correlation is a useful tool to study strain localisation in porous volcanic rocks. 